\title{
Moving from a Predominantly Teaching Oriented Culture to a Research Productivity Mission: The Case of Mexico and the United States
}

\author{
Gustavo Gregoruttia, ${ }^{\mathrm{a}}$ \\ ${ }^{a}$ University of Montemorelos, Mexico
}

\begin{abstract}
This study qualitatively analyzes the culture conflicts professors in the United States and Mexico are experiencing with the increasing pressures to produce more research about higher education. The first dataset was collected from 36 faculty members from 12 small and medium sized private, doctorate-granting universities. These universities are located in 11 states across the United States. The remaining data came from 44 faculty members employed at four small and medium sized private, doctoral granting universities in four states across Mexico. Results showed that universities in the US are transitioning from a predominantly teaching college culture to a more research orientation. Although the sampled universities continue to offer established graduate programs, faculty members continue to struggle with their teaching requirements and conflicts research productivity pressures place on their teaching and mentoring time with students. Participating faculty members employed in the US were not evenly interested in research opportunities due to the diverse mission objectives promoted by their respective institutions. On the other hand, faculty members employed in Mexico were generally more concerned with their research productivity and subsequent factors, which negatively impact their research productivity. Mexican faculty members rarely cited conflicts between their institutional missions and teaching objectives. This study is highly relevant to policy makers, higher education administrators, and scholars interested in comparative and international higher education. Administrators can benefit from the findings in this study, which provides faculty members' perceptions and describes departmental structures and organizational dynamics employed to advance greater research and development opportunities. This study concludes with a discussion on how administrators and faculty members should handle the pressures for research productivity and alternative models of higher education.
\end{abstract}

\begin{abstract}
Abstrak
Penelitian ini menganalisa secara kualitatif konflik kultural para staf pengajar di Amerika Serikat dan Meksiko yang dewasa ini semakin dituntut untuk menghasilkan lebih banyak penelitian tentang pendidikan tinggi. Data pertama diperoleh dari 36 orang pengajar di 12 universitas swasta kecil dan menengah yang menawarkan program doktor, berlokasi di 11 negara bagian di Amerika Serikat. Data kedua didapat dari 44 orang pengajar di 4 universitas swasta kecil dan menengah yang menawarkan program doktor, berlokasi di 4 negara bagian di Meksiko. Hasil penelitian menunjukkan, universitas di Amerika sedang mengalami transisi dari universitas yang berorientasi pengajaran menjadi universitas berorientasi penelitian. Walaupun program pascasarjana dari universitas Amerika ini cukup bagus, para staf pengajarnya masih kesulitan dengan berbagai persyaratan mengajar, dan mengalami konflik antara tuntutan memproduksi riset serta membagi waktu mengajar dan membina mahasiswa. Partisipan dari Amerika bahkan tidak semuanya tertarik melakukan penelitian, karena tujuan dan misi masing-masing institusi berbeda. Sebaliknya, partisipan dari Meksiko pada umumnya memiliki perhatian khusus terhadap produktivitas penelitian dan hal-hal terkait lainnya yang bisa berdampak buruk pada penelitian mereka. Selain itu, tidak banyak pengajar Meksiko yang melihat konflik antara misi institusi dan tujuan pengajaran. Penelitian ini sangat relevan bagi pembuat kebijakan, staf perguruan tinggi, dan ilmuwan yang tertarik dengan kajian komparasi dan pendidikan tinggi. Bagi staf administrasi, penelitian ini bermanfaat untuk mempelajari persepsi pengajar, susunan struktural dalam department, dan dinamika organisasi dalam mengembangkan peluang riset. Kesimpulan studi ini membahas bagaimana seharusnya para staf dan pengajar menyikapi tuntutan produktivitas riset dan beberapa model alternatif yang bisa diterapkan di perguruan tinggi.
\end{abstract}

Key words: Higher Education, Culture Conflict, Faculty Research Productivity, Small and Medium Private Universities 


\author{
*Corresponding author. Address: Catedrático Asociado, \\ University of Montemorelos, Nuevo León, México. \\ Email: grego@um.edu.mx.
}

\section{Introduction}

A new entrepreneurial trend among research universities has become visible since the 1980s. Many factors, such as escalating costs of labor and insurance, technological innovations, new government policies, and government budget cuts for higher education, have produced a greater demand for financial and operational resources (Slaughter and Leslie 1997; Newman et al. 2004; Gaffikin and Perry 2009). This increasing pressure is pushing universities to search more aggressively for external sources of funding (Francis and Hampton 1999; Clark 2003). In sum, universities are compelled to generate new sources of revenue to accomplish their goals. Liaisons with businesses, corporations, and foundations are becoming a common occurrence at many doctorate-granting universities, whether public or private (Bok 2003). At the same time, private corporations are supporting universities to enhance their businesses and access to markets (Slaughter and Rhoades 2004).

There has been a remarkable shift in the relationships between universities, the private sector, and the public sector (Powers 2004). Government legislation, such as the Bayh-Dole Act of 1980, in the US has encouraged nonprofit organizations and small businesses to retain the property rights to inventions derived from federally funded research (Powell and Owen-Smith 1998). Thus, the commercialization of research is permitted and encouraged through patents and the profitable licensing of university-industrygovernment partnerships. Legislation like the Bayh-Dole Act were implemented as a response to international events like the end of the Cold War and the rise of economic globalization, which prompted governments and businesses to operate under new paradigms (Berman 1998). Furthermore, at the time, corporations and large businesses needed external financial support to develop research and new technologies. According to Rosenbloom and Spencer (1996):

Within the large corporations, there was growing recognition that firms had become much less self-sufficient in their ability to generate the science and technology necessary to fuel economic growth. What was once a race has become more like a rugby match. They anticipate a diminishing role for corporate laboratories as the wellspring of innovation, and suggest that the 'seeds of new technological advance will probably sprout more often in university or government laboratories. (As cited in Powell and Owen-Smith 1998, 173)
These political and corporate shifts generated changes in the administrative and governance of universities and triggered "a second revolution" in higher education. According to Etzkowitz, Webster, and Healey (1998):

The academic revolution of the late nineteenth and early twentieth centuries introduced a research mission into an institution hitherto devoted to the conservation and transmission of knowledge. Building upon the first revolution, the second academic revolution is the translation of research findings into intellectual property, a marketable commodity, and economic development. (21)

This entrepreneurial environment continues to challenge the traditional mission objectives of universities. The "ivory tower" model of universities, where knowledge is produced in a pure form, is no longer feasible (Duderstadt 2000). Alternatively, universities are seen as boosters of economic development. At the same time, universities pursue professional networks with external resources to gain access to better facilities, increase budgets, improve research programs, and become financial stable (Becker and Lewis 1992; Bowie 1994; Lapidus, Syverson, and Welch 1995; Callan et al. 1997; Slaughter and Leslie 1997; Duderstadt 2000; Bok 2003). This new university paradigm focuses on a broader network of interdependent relationships in which the government and the private sector serve as partners for knowledge production. This is also known as the "Triple Helix Model" (Etzkowitz 1996).

This new administrative environment universities are experiencing is forged, to a grand extent, by the strong forces of Neoliberalism (Slaughter and Rhoades 2004). This is a political culture propelled by economic globalization that has promoted self-regulated markets, a reduction of government structures, and the rise of various technologies that have made enterprising individualism a well promoted activity (Ordorika Sacristan 2006; Graffikin and Perry 2009). However, not all universities are in position to adjust to global competition for research opportunities and subsequent resources in the same way (Pilbeam 2008). It is in this context that universities are finding alternative strategies (Clark 2003).

This new way or model of higher education operations is spreading from large to small research universities in developed and developing countries (Tien 2008). Mexico is no exception. From the government and elite universities, tertiary institutions are following a similar pattern as their US counter parts (Quddus and Rashid 2000). Through the National Council on Science and Technology (CONACYT), by far the most influential research organization in Mexico, the government links science and 
technology to research and development. CONAYCT is actively working to push universities under an umbrella of research productivity. It promotes accreditation as a way of controlling funding to professors and students. Institutions without an accreditation from CONACYT are not eligible for funds that are central to developing research agendas. To understand why the Mexican government prompted research as a key factor for accreditation and funding, it is necessary to understand the influence the Mexican government has over education. This is a much different picture when compared to the decentralized system in the US, where business, corporations, and private and state foundations support research in multiple ways.

According to these trends, many private and public universities around the world are committing themselves to the production of knowledge as one of the main objectives of their missions (Slaughter and Leslie 1997; Bok 2003; Powers 2004). Currently, research brings significant financial advantages and prestige that put institutions at the center of the academic world as the most sophisticated and qualified universities (Moore et al. 2001; Kim et al. 2003; Stack 2003). Therefore, many universities want to have what seems to be a key factor in succeeding in academia. This is especially true for numerous small and medium sized private research universities offering graduate degrees. These schools are struggling to generate research and keep pace with the standards of research productivity set by the top ranked research universities (Toutkoushian et al. 2003; Powers 2004). However, such institutions seem to have problems with balancing teaching and research. Faculty members at these institutions are often expected to teach a full load of classes while also working on research and publications endeavors (Blackburn and Lawrence 1995). These universities appear to be under a cultural transition where they are promoting themselves as institutions of research production that can have societal and technological influence. However, this transition challenges the way these universities are organized and creates budgetary situations that are rather complex to manage.

Many of these transitioning universities were colleges a few years ago. Over the last 20 years, the demand for graduate degrees has increased remarkably. Both in Mexico and in the US, people with graduate degrees improve their social status. Colleges and small universities have felt compelled to pursue university status and to offer more graduate degrees (Casanova 2006, Rubio 2006). This has created a conflicting transition that many of these new doctorate-granting institutions are facing. These universities are offering graduate degrees, but they are not as good at knowledge production. In sum, such universities are transitioning from a teaching culture to the research arena, which includes competing with large and established research universities (Scott 2006).

\section{Theoretical Framework}

One may ask why small and medium sized private universities are trying to imitate large and established research universities. A theoretical approach to understanding these changes in the increased competition for financial resources is what Di Maggio and Powell (1983) have called isomorphism, meaning the institutional trend that blurs differences among universities. Dey and colleagues (1997) examined the homogenization (isomorphism) of US higher education. Universities and colleges are copying each other and shaping themselves after one another. Consequently, institutions are losing their uniqueness. In other words, "institutions become less distinctive in form and character. These pressures are driven by strong economic and professional considerations and tend to promote institutional homogenization faster than institutional differentiation" (Dey et al. 1997, 309). The process of isomorphism is like a snakelike academic procession where the head (leading universities) move and the body (the remaining universities) follow (Riesman 1958, as cited in Dey et al. 1997, 309). The major problem with this standardization of academia is that higher education as a system may not be diverse to meet the wide needs of society. Consequently, these follower universities are experiencing some contradictory identity issues. Furthermore, not all higher education institutions can afford to become large, top ranked research institutions. Many universities seek to become reputable institutions as a means to have access to resources and gain prestige, but this is not a simple process (Dey et al. 1997; Serow et al. 1999). Only a select group of universities are able to gain significant profit through research opportunities and productivity. This is also called the accumulative advantage, also known as the "The Matthew Effect" (Merton 1968), where the rich become richer and the poor become poorer.

As aforementioned, trends in economic globalization and internationalization continue to influence the ways tertiary institutions react to changes and challenges. A new worldwide education model is developing and regional styles of conducting higher education operations are becoming more homogenized. However, not every higher education institution in the world is experiencing these effects in the same way (Barnett 2005). This is particularly the case of the sampled universities. To grasp the reasons of these adjustments, the theoretical approach known as the "system-reflection model" (Schriewer 2003), can help interpret the transition small and medium sized private universities in Mexico and the US are experiencing. The key concept of this model is the idea of "externalizations." According to Schriewer (2003): 
The system-reflection model, in contrast, highlights the adoptive mechanisms that are operative in varying national reflection contexts. More specifically, the externalization concept calls for particular attention to the interpretative reception and transformation, within the educational discourses of different nations or societies, of relevant world situations, bodies of knowledge, and educational models that have taken shape at the international level. (277)

Universities self regulate based on what is happening around them and implement "externalizations" to filter what to adopt according to their institutional needs and mission objectives. These externalizations, "make accessible both a system's international environment and its historical antecedents only in a filtered form, and in accordance with changing system-internal needs for supplementary meaning" (Schriewer 2003, 278). These processes are highly interpretative and selective. Institutions work based on an intertwined set of meanings and analysis of what happens around them. The idea of a floodgate (Schriewer 2003, 278) helps to understand the interactions occurring at the institutional level. Universities regulate the flux of innovation and change to avoid being flooded and denaturalized. Through complex mechanisms of self-regulation and exchange, institutions and professors sift what is going on around them. Institutions and professions open or close the floodgate based on assumed institutional missions. In other words, the externalizations are outward-inward relationships with the environment that have become globalized in this scenario. These externalizations are inescapable for all levels of human resources at universities since people at these institutions are affected by surrounding interactions. However, there is no neutrality in the way interactions affect actors. The unavoidable interpretation is built upon cultural backgrounds, such as national and regional values. At the institutional level, universities form recurring circuits of what is important, how things are done, and broad filters of approaching new events. Based on these ways of interacting and underlying assumptions, administrators and faculty members accept or reject what is being promoted as alternative operational procedures. An example of this interaction can be the strong promotion of research over teaching and training as a primary mission for universities. Professors adjust in ways that are, in many cases, unpredictable and not aligned with what a university's administration suggests to reform. In the end, a blend of reforms is produced that then needs to be appropriately analyzed by policy makers before seeking ways to implement a policy.

There are a variety of approaches to explain universities' pursuit of entrepreneurial activities, such as becoming more research oriented (Barnett 2005). Universities' traditions and sources of funding, human resources, and missions are examples of some of the ways universities attempt to pursue funding opportunities by connecting their research goals with sources of financial resources. Institutional operations, human resources, and circumstantial characteristics have a great deal of influence over an institutions' success in implementing an entrepreneurial reform (Meyer 2003).

Going into more detail about the dynamics of what occurs at the university level, Thomas and Dagnino (2005) examined three keen concepts to better understand the homogenization process that occurs at an institutional level. The first concept, translation, refers to the effort of keeping a concept's meaning within a system to later be transferred by using another meaning that will fit in the new place where the concept is inserted. The goal is "to adapt the institutional structures and the policies 'transferred' to the conditions of local context" (Thomas and Dagnino 2005, 17). This procedure is highly significant for policy makers who rewrite policies' meanings and functions, adjusting them to the context of the receiving institution. An example is the payment of bonuses based on research productivity that tends to be not well received in an environment where teaching has been the main activity to reward professors.

Second, the concept of migration is understood as the action from one system to the other. Migration involves interactions between people. For example, actor ' $A$ ' transfers a new meaning, desire, project, strategy, or idea to actor 'B,' but it does so in agreement with the established translations. This term is far from being objective, since the way translations are interpreted shape the process of migration. Consequently, the process of migration is always conducted through mediators or third parties that make the whole interaction very complex. When an institution invites a consultant to guide them to, for instance, increase research productivity, the migration of the ideas or project takes an understanding of the local context due to the practitioners' interpretations or translations. Therefore, what is transferred is quite different from what was proposed by the consultant.

Third, the concept of transduction refers to a "self organized process of meaning alteration that happens when an element (idea, concept, mechanism or heuristic tool) is transferred from a systemic context to another" (Thomas and Dagnino 2005, 19). Transduction also speaks to the syntactic effect that a message brings to the other systems and how it creates new meanings (functions, dysfunctions, and undesired effects). What is crucial in this concept is that "the supposed identity of the transferred element disappears in the phenomena of transduction. Only in the mind of the policy maker the new institution is identical to the original imitated" (Thomas and Dagnino 2005, 20). An internal 
change is happening, where the new element transferred is blended with the existing elements and becoming an altogether new element. Policies about producing research in a university that is already oriented to support and promote research has a different meaning when inserted in a context that promotes student services and teaching. The semantics of these policies need to be interpreted within a context to understand how it can alter an institution's basic purposes.

These constructs of translation, migration, and transduction allow administrators to understand what happens during the entire process of conceiving of a policy to implementing a policy. It might be useful for identifying why some policies are not working the way they were planned. Moreover, when a body of administrators set their eyes on, for instance, introducing research productivity as a model, the implementation and success is by far more complex than what is stated in writing. This can be even more difficult when copied models are imposed on the mission of universities without the proper processes and discussion of the involved stakeholders.

\section{Methodology}

This qualitative study explores a two-fold reality that commonly occurs in some doctorate-granting, private universities with low research performance. The first part is the perceptions about organizational environments and personal beliefs that encourage or prevent research productivity among selected faculty members from sampled universities in Mexico and the US. The second part is the conflicting cultural changes, which professors experience, that increase emphasis on research. Faculty research productivity is defined in this study as scholarly publication such as, articles, books, conference proceedings, and conference presentations.

The data for this paper was collected from Mexico and US. The amount of private universities in Mexico has been increasing over the last three decades (Rubio 2006). Some of these universities are moving from a predominately teaching approach to a more research orientation. The US system of higher education was also selected for this comparative study due to the extensive history private universities have within higher education. Many of these institutions are also experiencing a shift towards a more research orientation.

The first dataset was collected from 36 professors from 12 small and medium sized private doctorate-granting universities in 11 states across the United States (Carnegie Foundation 2007). The participants were surveyed with an open-ended questionnaire and agreed to participate in a follow-up qualitative survey as part of a larger research project that exceeds the present paper. Only 12 universities, out of 39 possible institutions listed by the Carnegie Classification (2007), gave permission to survey faculty members employed by them. By definition, these small and medium sized private universities graduate at least 20 doctoral candidates each year and offer three possible orientations: (a) humanities and social sciences (HSCD), (b) science, technology, engineering, and mathematics (STEM), and (c) professional fields other than engineering (PD) (Carnegie Foundation 2007). Most of the degrees offered at these 12 universities are PD programs.

Another dataset came from 44 professors employed at four small and medium sized private, doctorate-granting universities in four Northeast Mexican states. The 44 participants responded to the same open-ended questionnaire as their counterparts in the US. To ensure continuity, the four institutions from Mexico were chosen with the same criteria set by the Carnegie Classification for US universities. Proximity and access were also considered in selecting the institutions. Professors were randomly invited from all three orientations (HSCD, STEM, and PD) available within the four universities.

Finally, to further understand the dynamics between different research influences and research productivity, two sets of semistructured interviews were conducted with the sampled professors who demonstrated successful research productivity. Two professors were employed at one university in the US and two were employed at a university in Mexico. Both of the universities were from the original amount of sampled universities in each country. The interviewees were full-time professors with extensive records of publications and success in obtaining grants throughout their careers. The selection of these professors was based on references given by department chairs. The two sets of semi-structured interviews provided each participant the opportunity to answer the following introductory question: "What conditions or situations at this university enhance or deter the research process for you?" Follow-up questions were presented to the participants. The qualitative data collected through the openended questions were analyzed to establish common themes. Collective experiences were analyzed that may explain how faculty research is taking place within the selected universities. Finally, the two groups of participants, from Mexico and the US, were contrasted to analyze similarities and differences in perceptions about the way research is promoted or affected by institutional and personal factors. 


\section{Results}

Four main themes were ascertained from the open-ended questionnaires and interviews: (1) The need for publishing, (2) institutional characteristics and research, (3) promoting research, and (4) institutional emphasis and research. The contents are summarized with the central ideas using some quotations from professors to facilitate comparisons between professors from both countries.

\section{The Need for Publishing}

When professors were asked about their motivations and interests for producing research, they expressed several ideas that can be grouped under the theme of the need for publishing. Since these universities are evolving from a predominantly teaching culture, professors expressed a wide set of opinions regarding the relevance of research. They seemed to embrace the goal of producing papers and new ideas. Responses from Mexican and US professors unveiled similarly four broad motivations for producing knowledge:

1. Intellectual growth. Personal and intellectual growth appeared to be related to the advancement of new knowledge: "To grow intellectually as a person;" "to enhance my own intellectual development;" and "to share and test my thinking with others." Faculty members from both countries agreed that research is a means to grow through the development of scholarly activities.

2. Knowledge advancement and societal improvements. Research is increasingly seen as one of the central missions for these institutions (Boyer 1990; Fairweather and Beach 2002, Rubio 2006). In speaking to this concept, some professors said: "Duty to disseminate new knowledge we have produced, and a way of impacting society;" "To become a participant in the community of ideas; to take part in the conversations on topics of special interest; to grow intellectually as a person; to serve society and the church;" "Improve overall knowledge base and benefit society;" "To advance the current state of the art in my field;" Enhancing knowledge within a specific discipline is seen as a goal in itself, but also to use information to do something that would impact communities producing some kind of changes for their overall betterment."

3. To refresh and enhance teaching. Both the professors from the US and Mexico saw research as a way to improve teaching. In speaking to this concept, some professors said: "Keeps me excited about math and helps me share that excitement with my students;" "I need to conduct research both to improve my teaching and to maintain my standing in my university;" "Qualify myself as a teacher and adviser to students at all levels; "However, some American professors expressed contradictory statements regarding the relationship between research and teaching;" "We are losing our focus on students and quality teaching;" "If we spend too much time on scholarship, we can't focus on other aspects of our institutional mission." These perspectives are a probable a consequence of the emphasis new policies (from teaching to research) have on faculty members.

4. Professional prestige within and outside the university. Both in Mexico and in the US, universities and professors are searching for was to enhance their prestige (Baker and Wiseman 2008). As the following statements express: "Professional prestige and standing among colleagues in the field;" "Keep pace with colleagues I respect;" "Make myself more competitive on job market;" This prestige also brings external funding that is very much welcome in the context of these institutions;" "Improve chance of future grant proposals;" "Clout with funding agencies and reviewers obtaining more grants funded;" "It is hard to get research grants without prior publications." These responses illustrate that these professors strongly believe that research is linked to successfully obtaining financial resources.

The sampled professors from the US mentioned another reason why they are motivated to publish, namely "the pressure for tenure and promotion." This incentive model is a constant affirmation of the importance of research (Leslie 2002; Bland et al. 2006). These professors seemed to be concerned about meeting the demands of the reward system, and this, has continued to compel them to produce research. The incentives have increased due to the rising pressures for research outcomes. This may be a result of the growing need for external funding and prestige that institutions in the US are experiencing (Gaffikin and Perry 2009). In sum, administrators see research as a way to imitate the standards produced by large research universities and in the private and public sectors. Policies on promotion and tenure continue to be modified at small and medium sized private universities to meet such standards. However, the modifications still are not as extensive as those implemented by large, top ranked research universities.

Although the sampled professors in Mexico did not appear to experience the same pressures to generate research, these professors were in tune with the ideals and benefits of producing 
and publishing research. This group of professors did not discuss that research is a must for promotion. The concept of tenure in Mexico is more flexible and is mainly based on a wide range of activities that professors participate in. The promotion of faculty members is based more on teaching experience, years of service, and administrational activities. Although this is true for the sampled universities, it is necessary to clarify that the larger tertiary institutions, most of them state institutions, have a widely accepted system of rewards to promote professors. In other words, such universities in Mexico reward professors largely on research productivity. In following, some federal research organizations financially compensate entrepreneurial faculty members who are engaged in some kind of knowledge creation endeavors. An example of that is the National System of Researchers (SNI in Spanish) that funds researchers according to ranks of productivity. This system is controlled by the National Council on Science and Technology (CONACYT), a federal funded organization.

In short, this type of university from the US and Mexico, do not seem to have a highly structured system that enforces publications as extensive as top ranked research universities do (Blackburn and Lawrence 1995). As one professor from the US expressed, "When I was working at a research university, I had to published a certain amount of articles in peer reviewed journals whether I like it or not. It was a matter of publish or perish. Research productivity was part of your job. Here I see that productivity is an option." This is an area to be explored by policy makers at higher education institutions.

\section{Institutional Characteristics and Research}

Professors from Mexico and the US expressed concerns about their workload and time administrators give them to balance both research and teaching tasks. As some participants expressed: "Lower teaching loads would be a great help;" "better balance between teaching and research;" "less teaching and advising responsibilities." At the same time scholars from both countries, requested a more supportive and collaborative working environment to produce research. Some of the participants stated: "Better support of beginning research faculty would be the greatest help;" "Collaborative environment with a view toward partnerships and supportive administration." The need of training was also mentioned as a key factor for producing knowledge. As one professor from Mexico asserted, "We need more training to do research, we feel sometimes disoriented about doing serious research and especially tracking new sources of funding." This illustrates some of the cultural issues universities have. As one professor stated, "I wish the institution and other department respected publishing in a real way instead of just paying lip service to it. We need clarity on expectations." In addition, faculty members from both countries were looking for consistent mentoring, with clear rules and expectations that would mark a path for them to follow. According to professors' opinions, administrators did not seem to be consistent and understanding of what research processes take and the structures needed.

On the contrary, successful researchers from the sampled US universities revealed that they worked in an environment with clear expectations regarding the production of articles, books, and contributions to their disciplines. As one professor stated:

Within this department we enhance research or scholarship and it becomes part of the norms or expectations of the department. So, this department requires research contributions. We expect research as a norm. We don't understand if you don't. If you look at the statistics of the departments of biology, psychology, and behavioral sciences they are among the most scholarly in the university, what we call scholarly productivity points and all the scholarly research. So, we deal with a strong culture of scholarship.

This is a framework that gives professors a clear set of cultural expectations of what should be done, which leads to positive results. Something similar happens when administrators support research endeavors. According to another faculty member:

Our chair and when I was chairing, we both pushed research and we got institutional support for it. Here they expect you to teach four [classes], but we try and work so each faculty only teach three a semester if they are involved in scholarship. So we try to limit to three a semester. You have to be free to do research. We work together, we support together, we encourage together, and we help each other in terms of teaching a class if you are presenting somewhere. We are very supportive, expecting it and supporting you in order for you to meet your scholarly goals.

Confirming these findings, Hunter and Kuh (1987), studied prolific writers and found that scholarly success is enhanced when a sponsor nurtures a researcher from the beginning. A mentor is an important source of encouragement for potential investigators to develop their skills. This guidance is especially valuable for new professors. Perry and colleagues (2000) found that newly hired professors need a strong climate to nurture them to produce research. Also Dundar and Lewis (1998) discovered departmental 
characteristics that facilitate research productivity; among others nurturing was important (Kotrlik et al. 2002).

Finally, professors employed in the US pressed more for a clearer articulation of research and its importance to university and departmental missions. Policies for research agendas were not quite clear at the implementation level. On the other hand, Mexican professors emphasized the need of linking research with business and external sources of financial support:

We need more resources for our schools, since we are always falling short and very limited to carry on research projects. External funding is a great opportunity to expand our possibilities and do more. For instance, we can hire more graduate students and pay them with grants. But we don't really know how to do this.

This may be caused by the shortage of funding that some of these institutions are experiencing. The professors were also concerned with the lack of training to do research. Many of the professors from Mexico felt that they were not ready to handle a research project. According to one professor, "I feel that I would like to do more research, but I don't really know how to handle an external funded project." Training and time for conducting research are certainly central for the enhancement of knowledge.

\section{Promoting Research}

A small number of participants from both countries perceived their institutions as promoting more or less research and felt that there was some kind of mentoring environment in place at their respective institutions. As some of the participants stated:

Promotes, yes, we are encouraged to do academic discourse, and when we do produce something, it is nicely recognized. But there is no serious mentoring. I feel I am pretty much on my own;" "In theory, yes. But in reality, there is a real sense that administration lacks appropriate support." These professors also had higher levels of research productivity.

Some of the participants from the US reported that their departments did not promote research and believed that professors and institutions promoted different and conflicting ideals about the mission of higher education. These conflicting perspectives were a source of tension between both parties. For instance, one respondent said, "Most of our older faculty members were not hired to be researchers, but rather to be teachers. Thus, none of them really does research." Another participant stated, "None of them publish, they are scared of it and do not know what is going on in the field." Lastly, one participant described another conflict, "Our priority is on faculty who engage with students. Doing research takes away from faculty interactions, so we don't." The body of professors at these universities did not place the same emphasis on research, making research outputs more difficult. According to a participant, "My department is now promoting almost exclusively based on research. Which is a shame, because the operational funds come from tuition, and education is given short shrift." Expressions such as these symbolize an institutional rift that does not help professors' research productivity. Leadership and clear goals were lacking in such institutions. Consequently, the institutional environments do not align with previous research that found close relationships between departmental mission and research productivity (Goodwin and Sauer 1995; Creamer 1998; Dundar and Lewis 1998).

Scholars from both countries have worked in environments with unequal situations. Within the same university, some departments promote and mentor research as part of their missions, while others do not. Inconsistencies between departmental and institutional missions clearly influence professors' understanding of the importance of research productivity by sending contradictory messages. For example, "Non-research faculty are visibly threatened by the research productivity of newer faculty, and often hold it against them." Some professors circumvent such challenges by collaborating with colleagues as a way to create an informal culture of research orientation. According to a professor who engages in such collaborative efforts, "Informally, my colleagues and I are highly supportive of the various kinds of professional work each of us does, including but not limited to individual research efforts." Such efforts illustrate professors' commitments to research productivity. In short, both faculty members from Mexico and the US share similar perceptions about the way their departments or institutions promote research productivity. In some cases, conflicting messages can explain lower research outcomes among some of the professors.

\section{Institutional Emphasis and Research}

An important question in this study is whether faculty members believe that their institutions should shift to a more research orientation? The overwhelming majority of participants from both countries agreed that research inquiry is a positive objective that improves teaching, the overall production of knowledge, and their universities' reputation in academia. Furthermore, a majority of the participants also agreed that their respective institutions needed to promote and conduct more research. As one participants from a university in the US stated: 
This is a teaching college, but it suffers from lack of faculty who are abreast of the latest developments in their fields. People just keep teaching the same old material and the college suffers from low level of quality we need more academic rigor!

However, several participants from the US did not see a need for their institutions to move toward a more research orientation. The primary reason is based on their respective institutions' missions of teaching and serving students instead of promoting research efforts. Research has been seen as hindering teaching and mentoring students. According to some of the participants, "We are losing our focus on students and quality teaching;" "We are a teaching institution. That doing more research would lessen our quality and our mission;" "We are a teaching college and almost every 'productive' faculty researcher I know is disliked by their students because they don't have time for them."

Some of the US participants were divided between those supporting research, talking about its benefits, and those who manifested doubts on the relationship of research orientation with quality teaching. However, there was a small group of the participants who explored the idea of balance between teaching and research. Some of these participants stated, "The pendulum is now completely on the research side. It needs to come back to some equilibrium;" "I think we have enough of a research emphasis, but perhaps not enough appreciation of the differences in the nature of research in different disciplines." These professors seemed to be concerned with their universities' institutional missions and their implications for teaching, service, and research. Fears of misbalance may also thwart research, as this professor described:

Our board is pushing us in the direction of more research, but without funding the research or decreasing our teaching loads. Ultimately, both our teaching and our research will suffer. I prefer the ethos of teaching institutions (less competitive, fewer prima donnas on the faculty).

For these faculty members, balancing their professional activities seemed to be crucial for both their happiness and quality of their work. Large research universities face similar problems (Middaugh 2001), although their research culture is stronger (Campbell 1997). One of the US professors mentioned an issue that might be the central characteristics of such universities, the ideal of being a teaching university that teaches and trains students to be professionals and economically productive citizens:

Universities are places where discovery happens. If you are not writing the text, if your materials are not in the text, why bother calling yourself university? Don't hyphen yourself with teaching-university. There is no such thing as a "teachinguniversity." What is that? Universities are places of discovery. Universities are places where you discover, not only repeat the works of others. It is where you create the knowledge that you teach to your students. If you are just repeating the works of other, you are not a university.

The idea of a teaching university was a concern that many of the US professors mentioned. It is based on the idea that higher education is for training and not searching for new knowledge. Conversely, Mexican professors did not argue about the teaching or research model. It appears that most of the Mexican private universities are adopting a more research orientation or model as a valid model and they must align themselves with the subsequent objectives. In short, faculty research productivity seemed to be encouraged by an environment that nurtures professional development, research expectations, networking with other researchers within or outside of professors' institutions, and a mentoring atmosphere that promotes commitment to research (Boardman and Bozeman 2007). Another variable discussed to varying degrees by the participants is the need for more time and resources to produce research.

In general, faculty members admitted the importance of producing scholarly work as part of their career. US professors appeared divided when asked about what direction their department and university should take regarding research. Members from these universities expressed conflicting views about their roles. The main contradiction emerged around the distribution of their time. Some professors felt that devoting more time to research would diminish their quality instructional time with students. The coexistence of conflicting points of view regarding missions and faculty roles led to a lack of collaboration among professors. On the other hand, Mexican faculty members were more concerned with the rate of research productivity and the factors that can hinder research productivity. References to conflicts of mission and teaching balance were nonexistent. The professors seemed to want to engage in research productivity without knowing the effect of what research productivity may have on their teaching routines. Mexican professors expressed a higher interest in linking research and new sources of revenue, as a probable way to gain access to financial resources. 
Essential, some of the results delineated that these institutions are still evolving from a teaching college culture to a more research orientation. Although the sampled universities continue to offer established graduate programs, faculty members continue to struggle over the right budget, teaching load, and resources to produce more research. Both groups of faculty members were in a transition not only to the third mission (transferring knowledge to profit) but also, and at the same time, from the first (teaching) to the second mission (research).

\section{Discussion}

The discussion is divided into two sets of analyses. The first one discusses faculty research productivity and the institutional cultural and administrational problems that impact such efforts. The second section details the macro and political issues that affect universities' research productivity and efforts in Mexico and in the US.

\section{Faculty Research Productivity}

Following the literature review and data presented in this study, it seems that the traditional roles for universities are being challenged. Higher education as a system is facing changes that force universities to be more entrepreneurial, embarking in endeavors and incorporating institutional values not seen a few decades ago. This is especially true for this sample of small and medium sized private institutions in Mexico and in the US.

What might be an obvious mission to a large research university is not as clear to small and medium sized private universities in both Mexico and the US. These universities have evolved from colleges to doctorate-granting institutions, finding themselves at a crossroad that is compelling them to transition to adopt a proactive research agenda (Serow et al. 1999). There are many stakeholders involved in administering the transition and who are affected by the results of such a transition. Administrators seek to expand research productivity as a way of increasing prestige and resources in a competitive market. The sampled professors who participated in the study seemed to have a mixed reaction regarding research and teaching activities, as well as how these activities affect tenure and promotion (Wolverton 1998).

In the context of important institutional changes, a critical question for invested stakeholders is what can be done to help increase research productivity? Taken as a whole, the findings of this study clearly indicate that faculty research productivity for professors in Mexico and in the US, involves personal and institutional efforts. The participants documented several motivators to publish, such as, career enhancement, promotion, commitment to research, better teaching, and advancing their disciplines. These results align with previous research (Massey and Zemsky 1994; Clark 1997; Serow 2000). Existing literature suggests that universities can do many things to advance research productivity, especially creating an encouraging working environment where faculty members feel supported and motivated to increase their research productivity. In other words, universities that promote and expect professors to do more research tend to have higher productivity. This can even happen despite the obstacles of limited personal and institutional financial resources (Hunter and Kuh 1987; Creamer 1998; Leslie 2002; Bunton and Mallon 2007). In sum, creating a culture of mentoring might be one way to resolve hesitations in research productivity.

According to Smeby and Try (2005), professors are more productive when they increase their involvement in professional development opportunities like conferences, presentations, and grant proposals. This is especially important for novice faculty members. According to Perry and colleagues (2000), institutional climate is a key factor for newly hired professors who aspire to have a successful career conducting quality research in their respective disciplines. Kolpin and Singell (1996) arrived at a similar conclusion saying that "the research productivity of a faculty member is not simply a function of individual skills but is also affected by the 'quality' of colleagues" (421). The data from this study supports these conclusions. Essentially, an outside network of colleagues and various professional development opportunities can increase research productivity by overcoming other institutional obstacles (Meador et al. 1992).

One important contribution from this study is the long-term influence of resources in research productivity. It can be very challenging for a professor to produce high-quality research reports while experiencing challenges with time management. Supporting these findings, Copp (1984) expressed that "the top five inhibiting factors for research productivity were "lack of time, heavy teaching workloads, lack of preparation and commitment, lack of adequate funding or funding solely for teaching, and too few prepared or credentialed faculty members"” (as cited in Collins 1993, 163). Administrators must provide the necessary structures to assist professors in balancing their time between teaching and research endeavors to encourage the production of new knowledge.

A majority of the sampled universities have departments with professional development programs that are less research productive to varying degrees. According to several studies (Gander 1999; Bradley 2000; Anderson 2001), science-oriented departments and universities are more productive in terms of research that are measured by publishing articles and books. 
However, opportunities for administrational policies to try to balance and expand research in other departments, such as the art sciences and humanities still remain. The appropriate institutional administrators and policy makers should tailor the standards for research to meet the unique context of each discipline to increase research productivity.

In short, while research is shown to be beneficial for increasing intellectual growth in academia and in addressing important societal issues (Boyer 1990), several studies (Patrick and Stanley 1998; Marsh and Hattie 2002; Lee and Rhoads 2004) found that the quality of teaching seemed to be negatively correlated to research endeavors. Fairweather and Beach (2002) also found that only 22 percent of professors are productive both in teaching and research. This illustrates the difficulties professors have in balancing their time to meet the requirements of both tasks. This is also a sign that professors appear to have difficulty identifying their respective institutions' mission objectives that can result when an institution transitions from a traditional teaching approach to a more research orientation (Becker and Lewis 1992; Bowie 1994; Lapidus et al. 1995; Callan et al. 1997; Slaughter and Leslie 1997; Duderstadt 2000;). Institutional administrators need to address such a transition to unify research productivity efforts. According to Blackburn and Lawrence (1995), "The shared understanding of the institution's mission and what is central to a particular academic unit in part shapes decisions about awarding tenure or committing institutional resources to faculty projects." (18)

\section{Macro Issues}

As discussed at the beginning of this paper, university administrators are trying to catch up to the ways universities are transitioning under different governing paradigms that encourage a more entrepreneurial orientation like research (Clark 2003). These transitions are occurring in universities around the world, particularly in Mexico and in the US. However, entrepreneurial orientations like research productivity are expensive. It demands cutting edge facilities, time to conduct research, and a host of other resources that are lacking in many small and medium sized private universities.

This is an issue of institutional mission objectives. In Mexico, the federal government has been creating various state funded research centers and promoting special grants for research and development, hoping to boost the economy (Rubio 2006). Such efforts beg the question, should private universities align with these research endeavors and the overall national research agenda? Moreover, can institutions really do so without suffering a metamorphosis that alienates them? The data presented in this study shows how some professors have experienced an institutional schizophrenia that has made them very skeptical of research endeavors, which has not improved research productivity.

In Mexico, the sampled universities are at a crossroads. To receive accreditation and subsequent access to government funds, institutions must support federal policies that enforce researchorientated curriculums and students and professors who engage in research endeavors. This is especially true for graduate programs where a majority of research occurs. The problem is that most of the private universities in Mexico are serving a nontraditional body of students who often work full-time (Boville et al. 2006). Such students find it challenging to actively participate in research efforts as compared to their colleagues who are full-time students. However, CONACYT, the main promoter of the push for research productivity at the graduate level fails to consider the aforementioned problem within the graduate student bodies. (Arredondo et al. 2006). This situation prompts the need for policy makers to rethink the parameters and assumptions used to define quality and the standards for research productivity so universities can compete at the same level for financial resources provided by the government.

While it is understandable that the Mexican government is concerned about quality with the increasing number of private universities established over the last two decades (Rubio 2006), it is also important to question the affects the one size fits all model used for accreditation and funding has on private universities. A suggested alternative to address this problem is to decentralize the accreditation process for private universities and to promote privately funded research endeavors. Mexico has a strong state control over education. This is an area that can be improved through diversifying models of governmental supervision.

In the case of US universities, there is currently no overarching federal government solely in charge of granting accreditations. Funding for research follows a much more independent pattern than in Mexico. There are thousands of private and public foundations, businesses, and donors that provide research opportunities to assist universities in their accreditation process. This occurs less in Mexico. Universities in the US have more flexibility in enhancing the quality of their human personnel and academic structures. This is particularly imperative for small and medium institutions since obtaining limited private and public grants is very competitive and highly aggressive. It is important to keep in mind that research is an important component for education, but to become a research university is a venture that may drain existing resources. As aforementioned, it is important 
for universities in Mexico and the US to be able to compete evenly for grants and other forms of financial resources. The differences in abilities and access between small and medium sized universities and large, top ranked universities should not be ignored (Bok 2003). Creativity must be exerted to overcome differences.

Finally, a warning should be expressed for both policy makers in Mexico and in the US. When administrators copy models through "externalizations" (Schriewer 2003), they do it from their own contexts and cultural dynamics. This must be recognized as a starting point. Importing ideas or model from universities that are not embedded in an institutional context can generate various disruptions in the goals these models are supposed to serve. Administrators must be aware that migrating ideas can be tricky and distortions may produce undesired side effects (Thomas and Dagnino 2005). These universities have the challenge of reinventing themselves to maintain their competitiveness.

\section{Conclusion}

If private, small and medium sized universities in Mexico and in the US want to increase research productivity, it can be inferred from this study that they should revise their mission objectives; provide more resources for scholarly activities, such as time, and foster a mentoring culture. This would capitalize the capacity professors already have to successfully engage in research endeavors, as well as to assist novice faculty members in their research efforts by creating a nurturing environment that can boost their academic career.

However, it needs to be noted that research productivity should not be seen as the only way of getting prestige or funding to climb up the ladder of success in terms of visibility. Research is also a powerful tool to improve teaching, to increase the production of knowledge in disciplines, and to address societal issues (Kezar and Eckel 2000; Waghid 2002; Johnsrud 2008). According to Gaffikin and Perry (2009), there is no determinism in following a neoliberal agenda of using knowledge to financial gains, as many lead research universities do:

Thus far, the strategy statements and plans of leading US universities demonstrate that there is no determinist logic influencing such choices. Whatever the structural pressures toward a convergent neoliberal and market-driven framework for institutional decision-making, there remains political space for the agency of staff, students, community, and state to intervene with an alternative agenda. (138)
The issues raised in this study are important variables in the discussion about how to define higher education and institutions in the twenty-first century. Furthermore, it is important for administrators of small and medium sized private universities to define their role in the changing paradigm governing universities. More specifically, such universities need to decide whether or not they have a more holistic mission with original and unconventional contributions, or if they need to continue to adopt many of the large research universities' performances (Dey et al. 1997, Checkoway 2001). Accordingly, the data studied clearly illustrates that institutional schizophrenia may cost these universities what they are trying to conquer, namely success. In this regard, there is no greater risk than attempting to adopt a policy or standards that do not match institutional contexts.

Policy makers from Mexico and the US must recognize that it is not advantageous for their higher education systems to lack diversity. Having a wide variety of university models is highly desirable since society has a broad range of needs. Policies encouraging universities to produce knowledge and tackle other important societal dimensions of society are required to enrich the social and economic standards and goals of each country. Small and medium sized private doctorate-granting universities need to rethink their institutional missions in the context of major social, cultural, and financial changes. This is arguable the biggest and most challenging task ahead for higher education institutions. It might be the most influential factor affecting faculty research productivity.

\section{References}

Anderson, Melissa. 2001. "The Complex Relations between the Academy and Industry: Views from the Literature." Journal of Higher Education 72 (2): 226-246.

Arredondo Galván, Víctor Pérez, Rivera Graciela, and Porfirio Morán Oviedo. 2006. "Políticas del Posgrado en México." Reencuentro, 5 (045): 1-23.

Baker, David, and Alexander Wiseman, eds. 2008. The Worldwide Transformation of Higher Education. Bingley, UK: Emerald Group Publishing Limited.

Barnett, Ronald. 2005. "Convergence in Higher Education: The Strange Case of Entrepreneurialism." Higher Education Management and Policy 17 (3): 51-64.

Bayh-Dole Act, 35 US C. $\S 200-212$ (1980).

Blackburn, Robert, and Janet Lawrence. 1995. Faculty at Work: Motivation, Expectation, and Satisfaction. Baltimore: Johns Hopkins University Press. 
Bland, Carole, Bruce Center, Deborah Finstad, Kelly Risbey, and Justin Staples. 2006. "The Impact of Appointment Type on the Productivity and Commitment of Full-time Faculty in Research and Doctoral Institutions." Journal of Higher Education 77 (1): 89-123.

Becker, William, and Darrell Lewis. 1992. The Economics of American Higher Education. Norwell: Kluwer.

Berman, Evan. 1998. Productivity in Public and Nonprofit Organizations: Strategies and Techniques. Thousand Oaks: Sage.

Boardman, Craig, and Barry Bozeman. 2007. "Role Strain in University Research Centers." Journal of Higher Education 78 (4): 430-463.

Bok, Derek. 2003. Universities in the Marketplace: The Commercialization of Higher Education. Princeton: University Press.

Boville Luca, Belén, Nohemí Argüello Sosa, and Noemí Reyes Castro. 2006. "La Acreditación Como Proceso Dinamizador Hacia la Calidad." Revista Electrónica Actualidades Investigativas en Educación 6 (1): 1-21.

Bowie, Norman. 1994. University-Business Partnerships: An Assessment. Lanham: Rowman \& Littlefield.

Boyer, Ernst. 1990. Scholarship Reconsidered: Priorities of the Professorate. New York: John Wiley \& Sons.

Bradley, Karen. 2000. "The Incorporation of Women into Higher Education: Paradoxical Outcomes?" Sociology of Education 73 (1): 1-18.

Bunton, Sarah, and William Mallon. 2007. The Impact of Centers and Institutes on Faculty Life: Findings from a Study of Life Sciences Faculty at Research-Intensive Universities' Medical Schools. Innovative Higher Education 32: 93-103.

Callan, Patrick, Joni Finney, and Kathy Reeves Bracco. 1997. Public and Private Financing of Higher Education: Shaping Public Policy for the Future. Phoenix: Oryx Press.

Campbell, Teresa Isabelle. 1997. "Public Policy for the 21st Century: Addressing Potential Conflicts in University-Industry Collaboration." Review of Higher Education 20 (4): 357-379.

Carnegie Foundation for the Advancement of Teaching. 2007. The Carnegie Classification of Institutions of Higher Education: 2005 edition. Retrieved January 8, 2006, from http://www.carnegiefoundation.org/classifications.

Casanova, Hugo. 2006. "México." In International Handbook of Higher Education (881-897), eds. James Forest and Phillips Altbach. Dordrecht: Springer.

Checkoway, Barry. 2001. "Renewing the Civic Mission of the American Research University." Journal of Higher Education 72 (2): 125-147.
Clark, Burton. 2003. "Sustaining Change in Universities: Continuities in Case Studies and Concepts." Tertiary Education and Management 9 (2): 99-116.

Collins, Beth. 1993. "A Review and Integration of Knowledge about Faculty Research Productivity." Journal of Professional Nursing 9 (3): 159-168.

Creamer, Elizabeth. 1998. "Assessing Faculty Publication Productivity: Issues of Equity." ASHER-ERIC Higher Education Report 26 (2): 2-126.

Dey, Eric L., Jeffery F. Milem, and Joseph B. Berger. 1997. "Changing Patterns of Publication Productivity: Accumulative Advantage of Institutional Isomorphism?" Sociology of Education 70 (10): 308-323.

Di Maggio, Paul, and Walter Powell. 1983. "The iron Cage Revisited: Institutional Isomorphism and Collective Rationality in Organizational Fields." American Sociological Review 48: 147-160.

Duderstadt, James. 2000. A University for the 21st Century. Ann Arbor: University of Michigan Press.

Dundar, Halil, and Darrell Lewis. 1998. "Determinants of Research Productivity in Higher Education." Research in Higher Education 39 (6): 607-631.

Etzkowitz, Henry. 1996. "From Knowledge Flows to the Triple Helix: The Transformation of Academic-Industrial Relations in the USA.” Industry \& Higher Education 10 (6): 337-342.

Etzkowitz, Henry, Andrew Webster, and Peter Healey. 1998. Capitalizing Knowledge: New Intersections of Industry and Academia. Albany: State University of New York Press.

Fairweather, James, and Andrea Beach. 2002. "Variations in Faculty Work at Research Universities: Implications for State and Institutional Policy." Review of Higher Education 26 (1): 97-115.

Francis, John, and Mark Hampton. 1999. "Resourceful Responses: The Adaptive Research University and the Drive to Market." Journal of Higher Education 70 (6): 625-641.

Gaffikin, Frank, and David Perry. 2009. "Discourses and Strategic Visions: The US Research University as an Institutional Manifestation of Neoliberalism in a Global Era." American Educational Research Journal 46 (1): 115-144.

Gander, James. 1999. "Faculty Gender Effects on Academic Research and Teaching." Research in Higher Education 40 (2): 171-184.

Golde, Chris, and George Walker, eds. 2006. Envisioning the Future of Doctoral Education: Preparing Stewards of the Discipline. San Francisco: Jossey Bass.

Goodwin, Thomas, and Raymond Sauer. 1995. "Life Cycle Productivity in Academic Research: Evidence from 
Cumulative Publication Histories of Academic Economists." Southern Economic Journal 61 (3): 728-743.

Hunter, Debora, and George Kuh. 1987. "The "Write Wing": Characteristics of Prolific Contributors to the Higher Education Literature." Journal of Higher Education 58 (4): 443-462.

Johnsrud, Linda. 2008. "Faculty Work: Making our Research Matter-More." Review of Higher Education 31 (4): 489-509.

Kezar, Adrianna, and Peter Eckel. 2000. Moving Beyond the Gap between Research and Practice in Higher Education. San Francisco: Jossey-Bass.

Kim, Mikyong, Gary Rhoades, and Dudley Woodard. 2003. "Sponsored Research versus Graduating Students? Intervening Variables Unanticipated Findings in Public Research Universities." Higher Education 44 (1): 51-81.

Kolpin, Van, and Larry Singell. 1996. "The Gender Composition and Scholarly Performance of Economics Departments: A Test for Employment Discrimination." Industrial \& Labor Relations Review 49 (3): 408-423.

Kotrlik, Joe, James Bartlett, Chadwick Higgins, and Heather Williams. 2002. "Factors Associated with Research Productivity of Agricultural Education Faculty." Journal of Agricultural Education 43 (3): 1-10.

Lapidus, Jules, Peter Syverson, and Stephen Welch. 1995. "Postgraduate Research Training in the United States." In Research Training Present and Future, ed. Stuart. Blume. Paris: OECD Publication Service.

Lee, Jenny, and Robert Rhoads. 2004. "Faculty Entrepreneurialism and the Challenge to Undergraduate Education at Research Universities." Research in Higher Education 45 (7): 739-760.

Leslie, David. 2002. "Resolving the Dispute: Teaching is Academe's Core Value." Journal of Higher Education 73 (1): 49-73.

Marsh, Herbert, and John Hattie. 2002. "The Relation between Research Productivity and Teaching Effectiveness: Complementary, Antagonistic, or Independent Constructs?" Journal of Higher Education 73 (5): 603-641.

Massey, William, and Robert Zemsky. 1994. "Faculty Discretionary Time: Departments and the Academic Ratchet." Journal of Higher Education 65 (1): 1-22.

Meador, Mark, Stephen Walters, and John Jordan. 1992. "Academic Research Productivity: Reply, Still Further Results." Economics of Education Review 11 (2): 161-167.

Merton, Robert. 1968. "The Matthew Effect in Science." Science 159: 56-63.

Meyer, Martin. 2003. “Academic Entrepreneurs or Entrepreneurial Academics? Research-Based Ventures and
Public Support Mechanisms.” R\&D Management 33 (2): 107115.

Middaugh, Michael. 2001. Understanding Faculty Productivity. Standards and Benchmarks for Colleges and

Universities. San Francisco: Jossey-Bass.

Moore, William, Robert Newman, and Geoffrey Turnbull. 2001. "Reputational Capital and Academic Pay." Economic Inquiry 39 (4): 663-671.

Newman, Frank, Lara Couturier, and Jamie Scurry. 2004. The Future of Higher Education: Rhetoric, Reality, and the Risks of the Market. San Francisco: Jossey-Bass.

Ordorika Sacristan, Imanol. 2006. "Educación Superior y Globalización: Las Universidades Públicas Frente a una Nueva Hegemonía." Andamios 3 (5): 31-47.

Patrick, William, and Elizabeth Stanley. 1998. "Teaching and Research Quality Indicators and the Shaping of Higher Education." Research in Higher Education 39 (1): 19-41.

Perry, Raymond, Clifton Rodney, Verena Menec, Ward Struthers, and Robert Menges. 2000. "Faculty in Transition: A Longitudinal Analysis of Perceived Control and Type of Institution in the Research Productivity of Newly Hired Faculty." Research in Higher Education 41 (2): 165-194.

Pilbeam, Colin. 2008. "Designing an Entrepreneurial University in an Institutional Setting." Higher Education Policy 21: 393404.

Powell, Walter, and Jason Owen-Smith. 1998. "Universities as Creators and Retailers of Intellectual property: Life Sciences Research and Commercial Development." In To profit or not to Profit: The Commercial Transformation of the Nonprofit Sector, ed. Burton Weisbrod. New York: Cambridge University Press.

Powers, Joshua. 2004. "R\&D Funding Sources and University Technology Transfer: What is Stimulating Universities to Be More Entrepreneurial?" Research in Higher Education 45 (1): $1-23$.

Quddus, Munir, and Salim Rashid. 2000. "The Worldwide Movement in Private Universities Revolutionary: Growth in Post-Secondary Higher Education." American Journal of Economics and Sociology 59 (3): 487-516.

Rubio, Julio. 2006. La Politica Educativa y la Educación Superior en México. México: Fondo de Cultura Económica.

Schriewer, Jürgen. 2003. "Globalization in Education: Process and Discourse." Policy Futures in Education 1 (2): 271-283.

Scott, John. 2006. "The Mission of the University: Medieval to Postmodern Transformations." Journal of Higher Education 77 (1): 1-39.

Serow, Robert, Catherine Brawner, and James Demetry. 1999. "Instructional Reform at Research Universities: Studying 
Faculty Motivation." Review of Higher Education 22 (4): 411 423.

Serow, Robert. 2000. "Research and Teaching at a Research University." Higher Education 40 (4): 449-463.

Slaughter, Sheila, and Larry Leslie. 1997. Academic Capitalism: Politics, Policies and the Entrepreneurial University. Baltimore: Johns Hopkins University Press.

Slaughter, Sheila, and Gary Rhoades. 2004. Academic Capitalism and the New Economy: Markets, State, and Higher Education. Baltimore: Johns Hopkins University Press.

Smeby, Jens-Christian, and Sverre Try. 2005. "Departmental Contexts and Faculty Research Activity in Norway." Research in Higher Education 46 (6): 593-619.

Stack, Steve. 2003. "Research Productivity and Student Evaluation of Teaching in Social Science Classes: A Research Note." Research in Higher Education 44 (5): 539-556.

Thomas, Hernán, and Renato Dagnino. 2005. "Efectos de Transducción: Una Nueva Crítica a la Transferencia Acrítica de Conceptos y Modelos Institucionales." Ciencia, Docencia y Tecnología 16 (31): 9-46.

Tien, Flora. 2008. "What Kind of Faculty Are Motivated to Perform Research by the Desire for Promotion?" Higher Education 55: 17-32.

Toutkoushian, Robert Stephen R. Porter, Cherry Danielson, and Paula R. Hollis. 2003. "Using Publications Counts to Measure an Institution's Research Productivity." Research in Higher Education 44 (2): 121-148.

Waghid, Yusef. 2002. "Knowledge Production and Higher Education Transformation in South Africa: Towards Reflexivity in University Teaching, Research and Community Service." Higher Education 43 (4): 457-488.

Wolverton, Mimi. 1998. "Treading the Tenure-Track Tightrope: Finding Balance between Research Excellence and Quality Teaching." Innovative Higher Education 23 (1): 61-79. 